\title{
S.M. VOLKONSKY AND THE REFORM OF THE SYSTEM OF HONORARY TITLES OF THE IMPERIAL THEATRES ACTORS
}

\author{
Petr N. Gordeev \\ Herzen State Pedagogical University of Russia, Saint Petersburg, Russian Federation
}

\begin{abstract}
The article, based on the archival sources for the first the time introduced into scientific discourse, deals with an attempt to reform the system of honorary titles for the artists of the Imperial theaters undertaken by director of the Imperial Theatres S.M. Volkonsky in 1899-1900. The research is based on the archival sources for the first the time introduced into scientific discourse. In the Russian Empire artists were awarded with two honorary titles: "soloist of His Majesty" and "honored artist of the Imperial theatres". Having taken the position of director, S.M. Volkonsky presented his project "Provisions" to the officials of the Court Ministry, in which he proposed to abolish the title of "honored artist", and to differentiate the "soloist of His Majesty" title and a special badge, which all the artists with the honorary titles had been given since 1895. After criticism by the representatives of the Ministry S.M. Volkonsky presented a new project in which he proposed to establish a two-rank award for the representatives of all kinds of performing arts, in which there would be the lowest level of the title - "honored artist" and the highest - "soloist of His Majesty". However, this project was not adopted as well by two reasons: 1) inappropriateness of awarding dramatic actors with the "soloist" title; 2) impossibility of achieving the first degree of the award after the second one. As a result the reform of honorary degrees was not carried out until 1917, largely due to the inexperience of S.M. Volkonsky in bureaucratic affairs.
\end{abstract}

Key words: S.M. Volkonsky, soloist of His Majesty, honored artist of the Imperial theatres, Ministry of Imperial Court, Imperial theatres.

\section{С.М. ВОЛКОНСКИЙ И ПРОЕКТ РЕФОРМЫ СИСТЕМЫ ПОЧЕТНЫХ ЗВАНИЙ АРТИСТОВ ИМПЕРАТОРСКИХ ТЕАТРОВ}

\author{
Петр Николаевич Гордеев \\ Российский государственный педагогический университет им. А.И. Герцена, \\ г. Санкт-Петербург, Российская Федерация
}

\begin{abstract}
Аннотация. В статье на основании архивных источников, впервые вводимых в научный оборот, рассматривается попытка реформирования системы почетных званий артистов императорских театров, предпринятая директором императорских театров С.М. Волконским в 1899-1900 годах. В Российской империи артисты награждались двумя почетными званиями: «солист Его Величества» и «заслуженный артист императорских театров». Вступив в должность директора театров, С.М. Волконский представил на рассмотрение чиновников Министерства двора проект «Положения», в котором предложил упразднить звание «заслуженного артиста», а присвоение звания «солиста» отделить от награждения специальным знаком (который с 1895 г. вручался всем артистам, награжденным почетными званиями). После критики, последовавшей со стороны представителей Министерства, Волконский представил новый проект, в котором предлагал устаноㄱ. вить для представителей всех видов сценического искусства двухстепенное награждение, в котором низшей степенью явилось бы звание «заслуженного артиста», а высшей - «солиста Его Величества». Однако и этот проект не получил хода - Волконскому указали на неуместность присвоения звания «солиста» драматическим актерам, а также на отсутствие в его предложении возможности достижения первой степени награды о после второй. В итоге реформа системы почетных званий так и не была осуществлена вплоть до 1917 г., в () значительной степени благодаря неопытности С.М. Волконского в бюрократических делах.
\end{abstract}


Ключевые слова: С.М. Волконский, солист Его Величества, заслуженный артист императорских театров, Министерство императорского двора, императорские театры.

Настоящая статья посвящена неизвестному до сих пор эпизоду истории русского сценического искусства - проекту реформы системы почетных званий артистов императорских театров, инициированной директором императорских театров С.М. Волконским в 1899-1900 годах. Актуальность заявленной темы видится в ее значении для исследования важного вопроса становления и развития отечественной наградной системы, частью которой являлись почетные звания артистов императорских театров.

Источниковая база работы практически целиком состоит из архивных материалов. Во многом это связано со спецификой проблемы почетных званий, с достаточно закрытой процедурой их пожалования; как отмечалось в справке, подготовленной чиновниками Канцелярии Министерства императорского двора (далее - МИДв) в мае 1906 г., «о пожаловании званием Солиста Его Величества не объявляется в "Правительственном Вестнике”, а сообщается лишь Директору Императорских Театров, который и чинит необходимые по сему предмету исполнения, как то: извещает о сем артиста, посылает ему знак и проч.» [4, л. 237 об.].

Таким образом, основной комплекс источников по указанной теме составляет деловая переписка различных учреждений и чинов МИДв, отложившаяся преимущественно в фондах Российского государственного исторического архива (РГИА). Прежде всего, следует отметить два наиболее информативных архивных дела: «О награждении артистов и артисток Императорских Театров званием солистов и солисток Его Императорского Величества и знаком, установленным для заслуженных артистов» (содержащее в себе сведения о награждениях почетными званиями за 1895-1910 гг. и важную служебную переписку, посвященную различным аспектам наградной практики [4, л. 1-362]) и «Об учреждении для артистов императорских театров особого знака отличия - золотой лиры» [7, л. 1-42], дополняющего, по интересующему нас вопросу, материалы первого дела.
В конце XIX столетия артисты российских императорских театров награждались двумя почетными званиями: «солист Его Величества» и «заслуженный артист императорских театров». Первое из них возникло не позднее 1846 г., когда оно было присвоено бельгийскому скрипачу А. Вьетану, работавшему в то время в России [6, л. 1, 106]. Второе появилось намного позже: 25 февраля 1895 г. Николай II утвердил проект «знака, учреждаемого для солистов Его Величества и для артистов Императорских Театров, прослуживших не менее 25-ти лет и удостоенных представления к пожалованию этим знаком»; первое награждение знаком без присвоения звания «солиста» состоялось в ноябре того же 1895 г. (его удостоилась актриса Александринского театра Е.Н. Жулева). Вскоре (начиная с 1896 г.) подобных награжденных стали называть «заслуженными артистами»; окончательно это название закрепилось в наградной практике в конце 1890-х годов [4, л. 6969 об., 71-72; 5, л. 186-187, 194].

Звание «солиста Его Величества», как отмечал в своих мемуарах бывший директор императорских театров В.А. Теляковский, считалось более высоким, чем «заслуженного артиста императорских театров». Он вспоминал о казусе, связанном с соперничеством Л.В. Собинова и Ф.И. Шаляпина: «Шаляпин был сделан солистом, а Собинов заслуженным артистом - опять обида, и успокоился Собинов лишь тогда, когда его тоже сделали солистом. При этом требовал в нашей контоpe, чтобы в афише, в отличие от Шаляпина, выставлялись оба его звания: и заслуженного артиста и солиста <..> он радовался, что у него, не как у Шаляпина, не одно звание, а два» $[14$, с. 410$]$. Приказание В.А. Теляковского ставить на афишах с выступлениями Л.В. Собинова лишь звание солиста и ответное требование Л.В. Собинова (юриста по образованию) «иметь по этому предмету письменное уведомление Конторы» [9, л. 101101 об.] вызвали целую переписку между Дирекцией и Московской конторой императорских театров. В частности, в справке, подготовленной чиновниками Московской конторы 
в начале октября 1913 г., говорилось: «В законе не имеется определения понятия, а также прав и преимуществ Заслуженных артистов Императорских театров и Солистов Его Величества, а следовательно, не установлено и разграничения между этими званиями.

Из ранее бывших примеров можно усмотреть, что перевод Заслуженных артистов в Солисты рассматривался именно как переход из одного звания в другое и никоим образом не понимался как добавление одного почетного звания другим - равнозначащим. Уважение к тому высокому званию, коим носители его были пожалованы - побуждало их пользоваться последне-полученным и никаких недоразумений на этой почве не возникало так, Феликс Кшесинский, получивший в 1898 г. звание Заслуженного артиста, а в 1903 г. пожалованный Солистом, именовался с тех пор исключительно последним званием. Казалось бы, это правило должно и впредь строго соблюдаться» [9, л. 102].

Тем не менее, хотя звания солиста и заслуженного артиста и были неравны по своему статусу, в награждениях ими все же не было последовательной иерархии - лишь трое артистов (Ф.И. Кшесинский, М.И. Петипа и Л.В. Собинов) имели оба звания (при этом во всех случаях пожалование в солисты состоялось позднее, что подчеркивало более высокий статус звания солиста). Примечательно, что среди солистов не было не только ни одного драматического актера или актрисы, но и ни одной балерины, не исключая даже М.Ф. Кшесинской - притом, что танцовщики балетамужчины среди награжденных подобным званием встречались (П.А. Гердт, Ф.И. Кшесинский, М.И. Петипа). Отметим также, что если звание солиста не предполагало даже обязательности службы в императорских театрах, не говоря о ее продолжительности, то для того, чтобы стать заслуженным артистом, изначально необходимо было прослужить на казенной сцене не менее 25 лет (впрочем, как отмечалось в представлении комиссара Временного правительства над бывшим МИДв Ф.А. Головина Временному правительству от 31 мая 1917 г., «в последнее время бывали и отклонения от этих требований») [10, л. 5-5 об.].

Вопрос о взаимоотношении обоих почетных званий поднимался еще в конце XIX в., в период краткого, но насыщенного событиями директорства С.М. Волконского. 26 ноября 1899 г. Волконский, состоящий в должности директора императорских театров, отправил два представления на имя министра двора барона В.Б. Фредерикса, в которых испрашивались награждения для дирижера московского Большого театра С.Я. Рябова и певца того же театра П.А. Хохлова. Вопреки сложившейся традиции (ранее певцы представлялись к званию «солиста Его Величества»), Волконский ходатайствовал о пожаловании обоим только «знака, установленного для заслуженных артистов» [4, л. 50, 52].

Необычность такого представления вызвала письмо к С.М. Волконскому и. д. заведующего Канцелярией МИДв К.Н. Рыдзевского от 10 декабря 1899 г., написанное по поручению министра двора. Рыдзевский интересовался, испрашивается ли для П.А. Хохлова только награждение знаком без звания «солиста» и сообщал, что «Г. Министру угодно было указать на желательность выработать Положение о награждении артистов упомянутым отличием, с подробным и точным обозначением:

1, будет ли сопряжено награждение названным знаком с пожалованием звания Солиста Его Величества или заслуженного артиста, или этим знаком будут награждаться и без упомянутых званий,

2, кто именно из лиц артистического персонала, по роду своей службы, может быть удостоиваем званием Солиста Его Величества и званием заслуженного артиста

и 3, какие условия выслуги необходимы для представления к упомянутому награждению» [7, л. $17-17$ об.].

Волконский в ответном письме от 21 декабря 1899 г. подтвердил, что испрашивается только награждение «знаком»; что же касается «Положения о награждении артистов», он сообщал, что составление его проекта «вошло в программу работ образованной по приказанию Его Высокопревосходительства Господина Министра "Комиссии для составления Общего Положения об Императорских Театрах"». Если же представление проекта Положения требовалось немедленно, в таком случае С.М. Волконский просил «не оставить меня по этому вопросу уведомлением» [4, л. 56-56 об.]. 
По-видимому, составление данного проекта было сочтено делом первостепенной важности, так как уже 20 января 1900 г. С.М. Волконский вошел с рапортом к министру двора, представляя выработанный в Дирекции театров «Проект Положения о награждении артистов Императорских Театров знаком, установленным для Солистов Его Императорского Величества и заслуженных артистов Императорских Театров». Документ состоял из четырех пунктов, которые мы приводим ниже целиком:

«1) Высочайше утвержденным 25 Февраля 1895 г. знаком Всемилостивейше награждаются артисты Императорских Театров (сценические деятели и члены администрации трупп) за особо выдающиеся заслуги.

2) Так как заслуги, за которые артисты Императорских Театров могут быть награждаемы знаком и правом именоваться Солистом Его Величества, специально-художественного характера, то представляется желательным не ограничивать выслугу его каким-либо сроком, а предоставить Директору Императорских Театров определять, когда тот или другой артист заслуживает быть представленным к этой награде. (Но даже и в случае самых выдающихся заслуг ранее пяти лет службы никто к знаку не представляется.)

3) Право именоваться Солистом или Солисткою Его Величества жалуется или при награждении знаком или впоследствии.

4) Определение срока, когда артист представляется к званию Солиста: при награждении знаком или впоследствии - предоставляется оценке Директора.

Примечание: Таким образом наименование "Заслуженного артиста Императорских Театров" упраздняется, тем же, которые уже имеют право так именоваться - предоставляется сохранить его» [4, л. 67-67 об.].

В Канцелярии МИДв проект Дирекции театров встретили критически. Делопроизводитель Канцелярии Н.И. Оприц по поручению своего начальства еще раз лично справлялся в Санкт-Петербургской конторе императорских театров о том, «к какому именно награждению представлены гг. Рябов и Хохлов» и получил ответ и. д. управляющего Конторой К.Р. Гершельмана, что Контора ходатайствует только о присвоении им Высочайше утвер- жденных знаков «без предоставления какихлибо званий» [4, л. 57 об.-58]. Затем, 25 февраля 1900 г. тем же Н.И. Оприцем была подготовлена рукописная справка, посвященная разбору проекта. Осветив вначале историю утверждения и пожалования «знака для Солистов и заслуженных артистов», Оприц перешел затем к разбору проекта «Положения» по пунктам. В первом из них Оприц подчеркнул неопределенность формулировки «сценические деятели», не предусмотренной законодательством. Разбирая второй пункт, он указал, во-первых, на то, что награждение званием «солиста» или знаком для заслуженных артистов исходило ранее в некоторых случаях «и непосредственно от благоусмотрения Его Величества», переданного затем министру двора или директору театров (так, в частности, были награждены Ф.И. Кшесинский и В.М. Чиарлоне) - это был ответ на содержавшуюся в тексте проекта «Положения» мысль о закреплении права представления к данным наградам за директором театров. Во-вторых, касательно минимального срока выслуги, необходимого для получения почетного звания (который в представленном С.М. Волконским проекте предлагалось сократить до пяти лет), Оприц подчеркивал, что, как правило, срок был гораздо большим (более 20 лет), и лишь в одном случае (с В.М. Чиарлоне) был понижен до 12 лет. Здесь автор справки ошибался - он не учел целый ряд пожалований в «солисты Его Величества» после гораздо меньшего срока службы (так, Л.С. Ауэр был пожалован через два года после поступления в императорские театры, Н.Н. и М.И. Фигнер - после семи лет службы $[8$, л. 5]).

В комментариях к третьему пункту проекта «Положения» Н.И. Оприц, разбирая случаи пожалования артистов почетными званиями, указывал, что званием «солиста» ранее награждались «оперные певцы и музыканты (в одном случае - 1-й Балетмейстер), причем пожалование это сопровождалось всегда награждением и особо установленным знаком». Пожалование же «знака» капельмейстеру (Э.Ф. Направнику), танцовщику (Ф.И. Кшесинскому), балетмейстеру (Л.И. Иванову) и драматическим актерам «не сопровождалось предоставлением звания солистов Его Величества. Ношение этими артистами знака, ус- 
тановленного для Солистов и заслуженных артистов», рассуждал Оприц, «побудило, повидимому, Дирекцию именовать упомянутых лиц в красной строке афиш “заслуженными артистами Императорских Театров”. Таким образом, сама практика установила, что Высочайше утвержденный знак артистического отличия есть выразитель присвоенного артисту известного звания: солиста или заслуженного артиста». В этом месте Н.И. Оприц сделал примечание: «Нельзя не упомянуть здесь, что в проекте Положения не определяется точно, кому же именно из артистического персонала разных категорий может быть испрашиваемо звание Солистов Его Величества».

Касательно четвертого пункта проекта, представленного С.М. Волконским, в котором предусматривалось разделение двух наград «знаком» и почетным званием «солиста», Оприц справедливо заметил, что в таком случае «возникает необходимость дать упомянутому знаку, установленному 25 фев[раля] 1895 г. “для Солистов и заслуженных артистов”, какое-либо другое наименование, иначе он не будет соответствовать своему назначению». Наконец, важный комментарий был оставлен Оприцем при разборепримечания к п. 4 проекта «Положения» (об упразднении звания «заслуженного артиста»): «Наименов[ание] “заслуженный артист" вошло в практику за последний год, очевидно, как соответствующее звание к пожалованному знаку для тех лиц артистического персонала, кои, по роду своей службы, никак не могут быть приурочены (так в тексте. - П. Г.) к представлению на пожалование "Солистом Его Величества". Упраздняя упомянутое звание, Дирекция оставляет его в заголовке представленного ею проектируемого Положения о награждении артистов знаком, установленным 25 фев[раля] 1895 г.».

Сделанный им детальный обзор проекта «Положения», по мнению Н.И. Оприца, высказанному им в заключение «Справки», выяснил «некоторую неопределенность и неполноту этих вновь вводимых правил, требующих дальнейшей разработки и урегулирования» [4, л. 69-72].

Реформирование правил пожалования артистов императорских театров почетными званиями, таким образом, затягивалось. Тем временем, вопрос о награждении С.Я. Рябова и П.А. Хохлова необходимо было решать быстрее. Этим было вызвано письмо К.Н. Рыдзевского к С.М. Волконскому от 29 февраля 1900 г., в котором Рыдзевский, «имея в виду некоторую неопределенность и неполноту проектируемого Дирекциею Император[ских] театров положения об упомянутом награждении» предлагал «вопрос о награждении названных лиц разрешить на основании прежде бывших примеров», а именно «войти с всеподданнейшим докладом об испрошении гл[авному] дирижеру балета Рябову - звания заслуженного артиста и певцу Хохлову - звания Солиста Его Величества, с предоставлением этим лицам знаков, установленных для заслуженных артистов» [4, л. 59-59 об.]. Ответное письмо С.М. Волконского выявить пока не удалось; однако очевидно, что его реакция на предложение Рыдзевского могла быть только отрицательной - Волконский уже подтверждал ранее, что испрашивает для Хохлова только знак, не считая его, по-видимому, достойным награждения званием «солиста» (в итоге певец так и остался «заслуженным артистом»).

28 марта 1900 г. К.Н. Рыдзевский отправил подробное послание С.М. Волконскому, в котором представленный последним 20 января проект разбирался по существу. В подготовке документа большую роль сыграл Н.И. Оприц - на черновике (машинописном), отложившемся в фонде Кабинета Его Величества в РГИА, сохранились многочисленные пометы и исправления, сделанные его рукой, вошедшие затем в окончательный текст документа ${ }^{1}$. Данное письмо можно свести к нескольким основным возражениям на проект, представленный С.М. Волконским. Первое из них касалось порядка награждения почетным званием - соглашаясь с тем, «что Директору Императорских Театров желательно предоставить преимущественное право предварительной оценки артистической деятельности, заслуживающей представления к этой награде», Рыдзевский (и Оприц) отмечали, что предоставление директору театров «исключительного права удостоения этим знаком отличия, независимо от срока службы артистов, являлось бы не соответствующим первоначальной идее учреждения этого знака, освя- 


\section{ИСТОРИЯ РОССИИ}

щенной последующей практикою. < ..> казалось бы, что пределы компетенции Директора Императорских Театров представляются слишком расширенными за счет установленных порядком службы пределов власти Министра Императорского Двора по всякого рода награждениям» [7, л. 20-20 об.].

Помимо того, внимание С.М. Волконского обращалось на необходимость «ограничить круг лиц, могущих быть удостоенными награждением установленным знаком, исключительно указанным в законе артистическим персоналом 1-го разряда, отнюдь не распространяя этого права на лиц театральной администрации, а также на артистов, несущих службу по технической и хозяйственной части в Императорских Театрах». В письме Рыдзевского говорилось также о «неравномерности проектируемого награждения в отношении лиц, имеющих возможность, по свойству их сценической деятельности, воспользоваться правом именоваться Солистами Его Величества и относительно всех остальных артистов, которые, по проекту Дирекции Театров, могут быть удостоены награждения лишь одним знаком» (заметим, что в проекте Дирекции не уточнялось, какие именно категории артистов имеют право на пожалование званием солиста, но Канцелярия МИДв, видимо, исходила из того, что это могут быть только музыканты и артисты оперы и балета). Наконец, в письме отмечалось, что «предоставление права ношения упомянутого знака отличия, без соответственного пожалования одновременно с этим звания Солиста Его Величества или другого какого-либо наименования, неминуемо влечет за собою недоумение: какое название должно быть присвоено в этом случае знаку». Рыдзевский предлагал в таком случае называть его «хотя бы знаком отличия за сценическую деятельность». К письму прилагался проект положения о награждении артистов императорских театров почетными званиями, разработанный в Канцелярии МИДв; Рыдзевский просил Волконского «по согласовании упомянутого проекта с могущими оказаться требованиями Дирекции Императорских театров и условиями артистической службы, войти к Министру Императорского Двора с окончательным представлением по этому предмету» [7, л. 20 об.-21 об.].
Упомянутый проект был составлен в Канцелярии МИДв в марте 1900 г. (возможно, первоначальный его вариант был готов уже 10 января [4, л. 64]). Он состоял из восьми пунктов и в общем содержал те же идеи, которые были изложены К.Н. Рыдзевским в цитированном выше письме к С.М. Волконскому: согласно проекту, знаком (который назывался «знаком отличия за сценическую деятельность») могли быть пожалованы только «актеры, занимающие первые амплуа во всех родах драматического искусства, капельмейстеры, балетмейстеры, дирижеры оркестров, музыканты-солисты и танцовщики-солисты» ${ }^{2}$ [изначально в этом ряду были перечислены также управляющие труппами, режиссеры и декораторы, но затем данные категории театральных служащих были кем-то (К.Н. Рыдзевским? Н.И. Оприцем?) перечеркнуты]. Награждение знаком могло быть и самостоятельной наградой, и сопровождаться награждением почетным званием (последнее же, напротив, предусматривало и обязательное награждение знаком). Что касается званий, то они были распределены в соответствии с родами артистической деятельности - если оперные и балетные артисты, а также музыканты, награждались званием «солиста Его Величества», то «все остальные лица артистического персонала» - званием «заслуженного артиста». Таким образом, проект предусматривал двухстепенную систему награждения, в которой нижнюю степень представляло пожалование знака отличия за сценическую деятельность, а верхнюю - награждение одним из почетных званий (предусматривавшее также и вручение знака). В этом смысле замысел чинов Канцелярии МИДв был вполне логичным.

Что касается порядка награждения, то в проекте подчеркивалось, что награждение почетными званиями «зависит от Всемилостивейшего Его Императорского Величества благоусмотрения», однако министру двора предоставлялось право входить со всеподданнейшим докладом о награждении почетным званием или знаком артистов, «обративших на себя внимание своею выдающеюся артистическою деятельностью». Что же касается директора театров, то его роль сводилась к тому, чтобы, когда он «признает желательным 
поощрить этим званием или знаком артистов Императорских Театров за их артистические заслуги», входить об этом с представлением к министру двора «в установленном порядке» [4, л. 76-77 об.].

Проект, составленный в Канцелярии МИДв, не удовлетворил, однако, С.М. Волконского, который подверг его критике в своем письме К.Н. Рыдзевскому от 18 апреля 1900 года. Письмо, сохранившееся в архивном деле, испещрено интересными и содержательными замечаниями, сделанными, судя по почерку, Н.И. Оприцем (приводим их в сносках). «Из практики выясняется», писал Волконский, «что пожалование “знака для солистов и заслуженных артистов” носило двоякий характер. Иногда знак жаловался за выдающиеся артистические достоинства, при сравнительно малом количестве лет службы ${ }^{3}$, и сопровождался наименованием Солиста Его Величества. В других случаях он жаловался после сравнительно долгой службы не столько за выдающиеся артистические достоинства данного лица, сколько за полезную и почтенную артистическую деятельность, и в этих случаях жалуемый знаком получал звание заслуженного артиста. Такая практика минувших лет ${ }^{4}$ как бы устанавливает две категории, две степени пожалования знаком ${ }^{5}$, и мне подобный порядок представляется настолько логичным, что полагал бы его узаконить. Противоречием такой постановке вопроса являлись только случаи пожалования знака артистам драматическим, которые хотя и подходили под первую категорию, тем не менее получали наименование не Солиста, а Заслуженного артиста; это ставило драматических артистов, имеющих знак, на одну доску с заслуженными артистами других трупп, приравнивало их ко 2-й категории и таким образом как бы навсегда лишало их возможности дослужиться до награды первой степени» ${ }^{6}$.

Волконский указывал в своем письме два возможных способа исправления этой несправедливости. Первый заключался в том, чтобы признать: «Солист и Заслуженный артист - два равнозначущих титула, но в разных труппах». Однако, отмечал тут же князь, «тогда останутся без наименования все певцы, имеющие знак без звания Солиста» ${ }^{7}$. По- этому Волконский предлагал другой вариант: «Пожалование знаком имеет две степени ${ }^{8}$ :

I. C званием Солиста Его Величества.

II. C званием Заслуженного артиста.

Но в таком случае необходимым представляется распространить звание Солиста Его Величества и на драматических артистов ${ }^{9}$, а то они в силу своей специальности являются обреченными на награду 2-й степени».

Что касается срока выслуги, необходимого для получения почетного звания, то Волконский «полагал бы первую степень награды (знак с званием Солиста) не ограничивать никаким сроком службы (а если ставить minimum, то шесть, восемь лет), так как звание Солиста дается за выдающуюся артистичность, за исключительные художественные достоинства, а таковые присущи человеку помимо срока службы; иной и в 20 лет их не приобретет, а другой и в два года может сделаться гордостью Императорской сцены ${ }^{10}$. Наконец нельзя не принять во внимание, что если звание Солиста есть награда, то вместе с тем оно налагает и обязанность не только именоваться, но и быть солистом, а после 15-20 лет мало кто (из певцов) был бы способен оправдать свое наименование ${ }^{11}$. Представляется более естественным, чтобы звание Солиста жаловалось выдающемуся артисту в полном расцвете его сил.

Вторая степень награды (знак и звание Заслуженного артиста) дается за полезную и почтенную артистическую деятельность и здесь 15-20-летний минимальный срок представляется вполне уместным» ${ }^{12}$ [4, л. 7879 об.]. К письму Волконского был приложен составленный в Дирекции театров очередной вариант проекта «Положения», составленный по образцу прежнего проекта (созданного в Канцелярии МИДв), но с указанными в письме Волконского изменениями [4, л. 80-81].

После поступления в Канцелярию МИДв письма С.М. Волконского и приложенного к нему проекта чиновниками Канцелярии (вероятно, тем же Н.И. Оприцем) была составлена справка, в которой идеи директора театров подвергались критическому разбору. По вопросу о разделении почетных званий на две степени, одна из которых, по мысли Волконского, должна была даваться «за исключительные художественные достоинства» (солисты), 
а другая - «за полезную и примерную артистическую деятельность» (заслуженные артисты), в справке отмечалось: «Обращаясь к обзору списка Солистов и имеющих знак для заслуженных артистов нельзя не заметить, что все это лица, либо ныне пользующиеся хорошею славою и известностью, либо артисты, тоже бывшие в свое время кумирами толпы; что все они прослужили до получения этих званий значительное время, очень многие до 50 лет; что звание “Солиста” присваивалось певцам, музыкантам, танцовщикам, а знак, установленный для заслуженных артистов - персонажам драматических трупп и только в последнее время, 1899-1900 г., оперным певцам (Корсову, Хохлову).

Определить в этом списке лиц, пожалованных за свою талантливость и награжденных за почтенную и полезную службу представляется делом очень гадательным и вернее будет признать, что все эти лица награждены за их более или менее выдающуюся артистическую деятельность». Кроме того, автором справки было замечено, что «при таком делении артистических заслуг звание заслуженного артиста может быть испрошено каждому артисту Императорских Театров из первых персонажей, прослужившему не менее 15-20 лет, так как на образцовых Императорских сценах предполагается лишь выдающийся артистический персонал».

Предложение С.М. Волконского присваивать звание «солиста» драматическим актерам также было признано неудачным. Автор справки отмечал, что данное пожалование «представляется несколько необычным и не сродным с представлением об этом звании в применении к лицам, посвятившим себя драматическому искусству» [4, л. 64-65].

Несмотря на скептический разбор проекта, выдвинутого С.М. Волконским, в Канцелярии МИДв продолжали какое-то время размышлять над его идеями. Так, в цитированном архивном деле сохранилась небольшая табличка, составленная, судя по почерку, Н.И. Оприцем. В ней была сделана попытка соединения идеи Волконского о необходимости двухстепенного награждения с мнением чиновников Канцелярии о неуместности присуждения звания «солиста» артистам драмы. В таблице были расписаны две степени на- граждения; если низшей являлось звание «заслуженного артиста», вручаемое за «полезную и многолетнюю» артистическую деятельность в течение не менее чем 20 лет, то высшая степень (для которой был предусмотрен меньший служебный ценз - 6 лет) включала в себя два звания: «солиста» (им награждались певцы, музыканты и танцовщики) и равного ему по статусу «почетного артиста» (это звание предназначалось для драматических актеров и для дирижеров) [4, л. 82]. Последнее звание, впрочем, так никогда и не перешло из канцелярского черновика в наградную практику.

На этом завершились инициированные С.М. Волконским преобразования системы награждения артистов императорских театров почетными званиями. Как отмечалось в справке, подготовленной в 1910-1912 гг. ${ }^{13}$ (в связи с награждением званием «заслуженного артиста» Л.В. Собинова) чиновниками Канцелярии МИДв: «Особых правил, точно устанавливающих, какого именно разряда артисты могут быть удостаиваемы сим званием, - не имеется, а представленный бывшим Директором Императорских Театров Князем Волконским проект означенных правил, ввиду его несовершенства, дальнейшего движения не получил» $[12$, л. 2]. Как представляется, значительную роль в провале задуманного начинания сыграла яркая, но чуждая бюрократической премудрости личность C.M. Волконского, которого его преемник на посту директора театров характеризовал так: «В театре, с самого начала своей деятельности, он проявил себя молодым, симпатичным, образованным светским дилетантом, как большинство директоров и раньше, в служебном же отношении даже и не дилетантом, а совсем новичком, самым зеленым» [13, с. 36]. И действительно, Волконский, задумавший отменить звание «заслуженного артиста» и оставивший его при этом в заголовке выработанного в Дирекции театров проекта, затем решивший сохранить это звание, сделав его наградой «второй степени» - и не предусмотревший обязательного для таких случаев перехода в первую степень, демонстрировал свою крайнюю неопытность в служебных делах. Помимо того, одной из причин неосуществления реформы системы почетных артис- 
тических званий могла стать кадровая перестановка среди высших чинов МИДв: 1 января 1900 г. К.Н. Рыдзевский, много занимавшийся данным вопросом, был назначен и. д. управляющего Кабинетом Его Величества, а и. д. начальника Канцелярии МИДв стал А.А. Мосолов [1, с. 468; 2, с. 340, 468; 3, с. 166] (вероятно, этим и объясняется тот факт, что неоднократно цитированное нами архивное дело, содержащее переписку между Канцелярией МИДв и Дирекцией театров, отложилось в фондах Кабинета, так как ее продолжал какое-то время «вести» К.Н. Рыдзевский).

Таким образом, вплоть до Февральской революции в награждениях почетными званиями продолжало сохраняться определенное неравенство в пользу артистов музыкального театра, а четкие правила, в которых нуждалась наградная система, так и не были выработаны.

\section{ПРИМЕЧАНИЯ} 75 об.].

${ }^{1}$ См. черновой вариант документа [4, л. 74-

2 Как видим, в данном пункте, как и в его первоисточнике - примечанию к ст. 32 «Устава о службе по определению от правительства», в которой перечисляются «артисты первого разряда» [11, c. 142], отсутствует упоминание об оперных певцах - вероятно, они отнесены к «музыкантам».

3 На полях напротив этой фразы Н.И. Оприцем было замечено, что только Н.Н. и М.И. Фигнеры и В.М. Чиарлоне получили звание, прослужив менее 20 лет (что, как мы уже отмечали, фактически неверно - были и другие награждения после небольшого срока службы, например, в случае Л.С. Ауэра).

${ }^{4}$ Комментарий Н.И. Оприца: «Это только за последние годы».

${ }^{5}$ Комментарий Н.И. Оприца: «Две категории - не есть две степени (младшая и старшая)».

${ }^{6}$ Комментарий Н.И. Оприца: «Если звание Солиста дается за “выдающуюся артистичность", а звание заслуженного артиста "за почтенную артистическую деятельность”, то едва ли представляется возможным перескочить из одного звания в другое?».

7 Комментарий Н.И. Оприца: «И пусть остаются, как это и предполагалось в первом представлении в д[олжности] Директора Имп[ераторских] Театров от 20 Ян[варя] 1900 г. за № 187 пун[кт] 3».
${ }^{8}$ Комментарий Н.И. Оприца: «Деление на степени предполагает, по установленному порядку награждения, возможность повышения из одной степени в другую, что в данном случае неисполнимо».

${ }^{9}$ Комментарий Н.И. Оприца: «Едва ли это будет логичным наименованием?».

${ }^{10}$ Комментарий Н.И. Оприца: «едва ли?».

11 Комментарий Н.И. Оприца: «А будет ли оправдывать свое наименование "Солиста" лицо, хотя и награжденное этим званием за шесть лет службы, но на седьмом году спавшее с голоса?».

12 Комментарий Н.И. Оприца: «Еще подтверждение, что из “заслуженного артиста” нельзя стать “солистом”. По второй степени могут быть награждены все артисты, ибо предполагается, что не полезных Дирекция не держит».

13 Документ не датирован. Однако он тесно связан, с одной стороны, с находящейся на предыдущем архивном листе резолюцией В.Б. Фредерикса от 20 ноября 1910 г., а с другой - с занимающими последующие листы машинописными списками заслуженных артистов и солистов Его Величества, доведенными до 1911 г. (имеются позднейшие рукописные вставки о награждениях, бывших в 1912 г.) [12, л. 1, 3-5 об.].

\section{СПИСОК ЛИТЕРАТУРЫ}

1. 200-летие Кабинета Его Императорского Величества. 1704-1904. Историческое исследование. СПб. : Т-во Р. Голике и А. Вильберг, 1911. - 794 с.

2. Григорьев, С. И. Придворная цензура и образ Верховной власти (1831-1917) / С. И. Григорьев. - СПб. : Алетейя, 2007. - 476 с.

3. Любарская, Т. Г. Министерство императорского двора и его учреждения / Т. Г. Любарская // Высшие и центральные государственные учреждения России. 1801-1917. Т. 3. - СПб. : Наука, 2002.С. $145-188$.

4. О награждении артистов и артисток Императорских Театров званием солистов и солисток Его Императорского Величества и знаком, установленным для заслуженных артистов // Российский государственный исторический архив. - Ф. 468. Оп. 44. - Д. 923. - Л. 1-362.

5. О службе актрисы русской драматической труппы Екатерины Жулевой // Российский государственный исторический архив. - Ф. 497. - Оп. 5. Д. 1112.- Л. 1-209.

6. О службе скрипача солиста Его Величества Вьетан, Гейнриха // Российский государственный исторический архив. - Ф. 497. - Оп. 1. - Д. 10673. Л. 1-119.

7. Об учреждении для артистов императорских театров особого знака отличия - золотой лиры 
// Российский государственный исторический архив. - Ф. 497. - Оп. 6. - Д. 3963. - Л. 1-42.

8. Переписка с главноуполномоченным Комиссара по Государственным театрам о присвоении артистке Мариинского театра М.А. Славиной звания заслуженной артистки Государственных театров // Российский государственный исторический архив. - Ф. 472. - Оп. 66. - Д. 630. - Л. 1-10.

9. По личному составу оперной труппы // Российский государственный исторический архив. - Ф. 497. - Оп. 10. - Д. 1870. - Л. 1-132.

10. Представление Комиссара над бывшим Министерством двора Временному правительству о предоставлении артисту государственных театров Помян-Помазанскому И.А. звания заслуженного артиста // Государственный архив Российской Федерации. -Ф. 1779. - Оп. 1. - Д. 1638. - Л. 1-5 об.

11. Свод законов Российской империи. Издание неофициальное. - СПб. : Русское Книжное Товарищество «Деятель», 1912. - Т. ІІІ. Кн. 1. Устав о Службе по определению от правительства. - С. 1-179.

12. Списки заслуженных артистов и солистов императорских театров, справка о введении звания заслуженного артиста // Российский государственный исторический архив. - Ф. 472. - Оп. 66. Д. 299. - Л. 1-8.

13. Теляковский, В. А. Воспоминания 1898 1917 / В. А. Теляковский // Теляковский В. А. Воспоминания. - Л. ; М. : Искусство, 1965. - С. 17-222.

14 Теляковский, В. А. Мой сослуживец Шаляпин / В. А. Теляковский // Теляковский В. А. Воспоминания. - Л. ; М. : Искусство, 1965. - С. 349-412.

\section{REFERENCES}

1. 200-letie Kabineta Ego Imperatorskogo Velichestva. 1704-1904. Istoricheskoe issledovanie [200th Anniversary of the Cabinet of His Imperial Majesty. 1704-1904. Historical Research]. Saint Petersburg, T-vo R. Golikei A. Vilberg Publ., 1911. 794 p.

2. Grigoryev S.I. Pridvornaya tsenzura i obraz Verkhovnoy vlasti (1831-1917) [The Court Censorship and the Image of the Supreme Power (18311917)]. Saint Petersburg, Aleteya Publ., 2007. 476 p.

3. Lyubarskaya T.G. Ministerstvo imperatorskogo dvora i ego uchrezhdeniya [The Ministry of the Imperial Court and its Institutions]. Vysshie $i$ tsentralnye gosudarstvennye uchrezhdeniya Rossii. 1801-1917 [The Superior and the Central State Institutions of Russia. 1801-1917]. Saint Petersburg, Nauka Publ., 2002, vol. 3, pp. 145-188.

4. O nagrazhdenii artistov i artistok Imperatorskikh Teatrov zvaniem solistov i solistok Ego Imperatorskogo Velichestva i znakom, ustanovlennym dlya zasluzhennykh artistov [About Awarding Artists of the
Imperial Theatres with the Title of Soloists of His Imperial Majesty and the Sign for Honoured Artists]. Rossiyskiy gosudarstvennyy istoricheskiy arkhiv [Russian State Historical Archive], F. 468, Op. 44, D. 923, L. 1-362.

5. O sluzhbe aktrisy russkoy dramaticheskoy truppy Ekateriny Zhulevoy [About the Service of Actress of Russian Drama Troupe Ekaterina Zhuleva]. Rossiyskiy gosudarstvennyy istoricheskiy arkhiv [Russian State Historical Archive], F. 497, Op. 5, D. 1112, L. 1-209.

6. O sluzhbe skripacha solista Ego Velichestva V'etan, Geynrikha [About the Service of Violinist, Soloist of His Majesty Henry Vieutemps]. Rossiyskiy gosudarstvennyy istoricheskiy arkhiv [Russian State Historical Archive], F. 497, Op. 1, D. 10673, 1L 1-119.

7. Ob uchrezhdenii dlya artistov imperatorskikh teatrov osobogo znaka otlichiya - zolotoy liry [About Establishing the Special Distinction Sign for Artists of the Imperial Theatres - the Gold Lyre]. Rossiyskiy gosudarstvennyy istoricheskiy arkhiv [Russian State Historical Archive], F. 497, Op. 6, D. 3963, L. 1-42.

8. Perepiska s glavnoupolnomochennym Komissara po Gosudarstvennym teatram o prisvoenii artistke Mariinskogo teatra M.A. Slavinoy zvaniya zasluzhennoy artistki Gosudarstvennykh teatrov [The Correspondence with the Chief Representative of the Commissioner for the State Theatres on Assignment of Mariinsky Theatre's Actress M.A. Slavina with the Title of Honoured Artist of the State Theatres]. Rossiyskiy gosudarstvennyy istoricheskiy arkhiv [Russian State Historical Archive], F. 472, Op. 66, D. 630 , L. 1-10.

9. Po lichnomu sostavu opernoy truppy [About the personnel of the Opera company]. Rossiyskiy gosudarstvennyy istoricheskiy arkhiv [Russian State Historical Archive], F. 497, Op. 10, D. 1870, L. 1-132.

10. Predstavlenie Komissara nad byvshim Ministerstvom dvora Vremennomu pravitelstvu o predostavlenii artistu gosudarstvennykh teatrov Pomyan-Pomazanskomu I.A. zvaniya zasluzhennogo artista [The statement of the Commissioner over former Ministry of the Court to the Provisional government on awarding the state theatres artist I.A. PomianPomansky the title of honoured artist]. Gosudarstvennyy arkhiv Rossiyskoy Federatsii [The State archive of Russian Federation], F. 1779, Op. 1, D. 1638, L. 1-5 ob.

11. Svod zakonov Rossiyskoy imperii. Izdanie neofitsialnoe [The Code of Laws of the Russian Empire. Informal Edition]. Saint Petersburg, Deyatel Publ., 1912, vol. III. Book 1. The Charter about service by government's order, pp. 1-179.

12. Spiski zasluzhennykh artistov i solistov imperatorskikh teatrov, spravka o vvedenii zvaniya zasluzhennogo artista [The Lists of the Honoured Artists and Soloists of the Imperial Theatres, 
Certificate on the Establishing the Title of Honoured Artist]. Rossiyskiy gosudarstvennyy istoricheskiy arkhiv [Russian State Historical Archive], F. 472, Op. 66, D. 299, L. 1-8.

13. Telyakovskiy V.A. Vospominaniya 1898 1917 [Memoris 1898-1917]. Telyakovskiy V.A.
Vospominaniya [Memoris]. Leningrad, Moscow, Iskusstvo Publ., 1965, pp. 17-222.

14. Telyakovskiy V. A. Moy sosluzhivets Shalyapin [My Colleague Shalyapin]. Telyakovskiy V.A. Vospominaniya [Memoris]. Leningrad, Moscow, Iskusstvo Publ., 1965, pp. 349-412.

\section{Information About the Author}

Petr N. Gordeev, Candidate of Sciences (History), Associate Professor, Herzen State Pedagogical University of Russia, Naberezhnaya reki Moyki, 48, 191186 Saint Petersburg, Russian Federation, petergordeev@mail.ru, http://orcid.org/0000-0003-2842-4297.

\section{Информация об авторе}

Петр Николаевич Гордеев, кандидат исторических наук, доцент, Российский государственный педагогический университет им. А.И. Герцена, набережная реки Мойки, 48, 191186 г. Санкт-Петербург, Российская Федерация, petergordeev@mail.ru, http://orcid.org/0000-0003-2842-4297. 